\title{
Is enumeration district level an improvement on ward level analysis in studies of deprivation and health?
}

\author{
Roy Carr-Hill, Nigel Rice
}

\begin{abstract}
Aim - To investigate whether enumeration district (ED) level data reflect the aggregate characteristics of people living in that district better than ward level analysis.

Design and setting - Reanalysis of the fourth national morbidity survey in general practice (MSGP4). Socioeconomic data on patients who had consulted 60 practices over one year were linked via postcode to $E D$ and thence to small area statistics data for that ED and to the corresponding electoral ward.

Results and conclusions - There was no evidence that patients were likely to be more representative samples of the population of an ED than of a ward.
\end{abstract}

(f Epidemiol Comm Health 1995;49(Suppl 2):S28-S29)

There has been a long history of small area analysis of the relationship between health and deprivation, usually at the electoral ward level. Enhanced computing power and the availability of a wider range of data together with the increased capacity to link databases that have become available and a better link between postcodes and enumeration districts (EDs) will encourage an avalanche of analyses at ED level.

The Office of Population Censuses and Surveys (OPCS) has itself documented the possible bias when using ED data ${ }^{1}$ because of "Barnardisation" (the quasi-random addition of $-1,0,+1$ to all counts except basic population), and especially with the $10 \%$ sample tables. It is often assumed, however, that ED data will provide a closer reflection than ward data of the aggregate characteristics of in- dividuals living in that ED or ward. We query that assumption drawing on a reanalysis of the fourth national morbidity survey in general practice (MSGP4).

\section{Data and methods}

MSGP4 is a data set of all consultations over a year by all patients (n circa 500000 ) registered with 60 participating practices. ${ }^{2}$ Socioeconomic data were collected by means of a questionnaire administered to each individual. The questionnaire was based on a subset of the questions from the census. Information was collected from approximately 425000 individuals (a response rate of $85 \%$ ) and individuals were linked via the postcode to an enumeration district (ED) and thence to small area statistics (SAS) data for that ED and the corresponding electoral ward.

To ensure confidentiality, an explicit ED identification had been given only for those sample members where more than $20 \%$ of the ED's population or more than 100 individuals of the ward were in the study. The ED restrictions excluded over $30 \%$ of the sample members and the ward restriction around 5\%. This illustration is therefore based on individuals in the 1620 EDs and 480 wards where there are substantial members belonging to the MSGP4 sample.

The issue is whether individuals living in an ED or ward can sensibly be assumed to be characterised by the average value for that ED or ward. Taken literally, the proposition is obvious nonsense: no one in an ED is $15 \%$ unemployed. But, there is a real question as to how robust are the procedures currently suggested for making synthetic estimates.

\section{Results}

IS IMPUTATION VALID?

individual data at enumeration district (ED) and ward level

\begin{tabular}{|c|c|c|c|c|c|c|}
\hline \multirow{2}{*}{$\begin{array}{l}\text { Aggregated } \\
\text { individual data }\end{array}$} & \multicolumn{6}{|c|}{ Census $S A S$ data } \\
\hline & \multicolumn{2}{|c|}{$\%$ owner occupier } & \multicolumn{2}{|c|}{$\%$ council renting } & \multicolumn{2}{|c|}{$\%$ private renting } \\
\hline $\begin{array}{l}\% \text { owner occupier } \\
\% \text { council renting } \\
\% \text { private renting }\end{array}$ & $\begin{array}{r}.89 \\
-.77 \\
-.28\end{array}$ & $\begin{array}{r}.69 \\
-.62 \\
-.34\end{array}$ & $\begin{array}{r}-.76 \\
.92 \\
-.13\end{array}$ & $\begin{array}{r}-.60 \\
.87 \\
-\cdot 14\end{array}$ & $\begin{array}{r}-.19 \\
-.29 \\
.66\end{array}$ & $\begin{array}{r}-.29 \\
-.31 \\
.65\end{array}$ \\
\hline \multirow{2}{*}{$\begin{array}{l}\text { Aggregated } \\
\text { individual values }\end{array}$} & \multicolumn{6}{|c|}{ Census $S A S$ data } \\
\hline & $\begin{array}{l}\% \text { in class } \\
\text { I or II } \\
E D\end{array}$ & Ward & $\begin{array}{l}\% \text { in class } \\
I V \text { or } V \\
E D\end{array}$ & Ward & $\begin{array}{l}\% \text { in class } \\
I I M, I V \text {, or } \\
E D\end{array}$ & Ward \\
\hline $\begin{array}{l}\text { Class I or II } \\
\text { Class IV or V } \\
\text { Class IIM, IV, or V }\end{array}$ & $\begin{array}{r}.68 \\
-.57 \\
-.63\end{array}$ & $\begin{array}{r}.71 \\
-.63 \\
-.67\end{array}$ & $\begin{array}{r}-.51 \\
.54 \\
.51\end{array}$ & $\begin{array}{r}-.65 \\
.64 \\
.64\end{array}$ & $\begin{array}{r}-.64 \\
.61 \\
.68\end{array}$ & $\begin{array}{r}-\cdot 72 \\
.64 \\
.74\end{array}$ \\
\hline
\end{tabular}

Aggregated across all EDs or wards, there is very little difference between MSGP4 data and the census data, ${ }^{2}$ but although the diagonal correlations between aggregated individual sample data at ED and ward level with the SAS population values for tenure status variables are generally high, the correlations for social class variables are relatively low (table 1 ). There is, of course, likely to be a bias because individuals on GP lists are not necessarily representative of their ED or ward, but there is no systematic difference between the correlations at ED and ward level. 
Table 2 Mean number of consultations for any reason by individual tenure status, social class, unemployment status, and by enumeration district (ED) and ward grouped by the corresponding proportions of sample members in that ED or ward

\begin{tabular}{|c|c|c|c|c|c|c|}
\hline \multirow[b]{3}{*}{ Social class } & \multicolumn{6}{|c|}{ Mean no of consultations } \\
\hline & \multicolumn{2}{|l|}{ Individual } & \multicolumn{2}{|l|}{$E D$} & \multicolumn{2}{|l|}{ Ward } \\
\hline & $\begin{array}{l}\text { Non-manual } \\
3.87\end{array}$ & $\begin{array}{l}\text { Manual } \\
4 \cdot 46\end{array}$ & $\begin{array}{l}\text { Non-manual } \\
3 \cdot 72\end{array}$ & $\begin{array}{l}\text { Manual } \\
4 \cdot 62\end{array}$ & $\begin{array}{l}\text { Non-manual } \\
3 \cdot 74\end{array}$ & $\begin{array}{l}\text { Manual } \\
4 \cdot 64\end{array}$ \\
\hline Tenure status & $\begin{array}{l}\text { Non-owner } \\
\text { occupier } \\
5.02\end{array}$ & $\begin{array}{l}\text { Owner } \\
\text { occupier } \\
3 \cdot 83\end{array}$ & $\begin{array}{l}\text { Non-owner } \\
\text { occupier } \\
4 \cdot 71\end{array}$ & $\begin{array}{l}\text { Owner } \\
\text { occupier } \\
3 \cdot 76\end{array}$ & $\begin{array}{l}\text { Non-owner } \\
\text { occupier } \\
4 \cdot 77\end{array}$ & $\begin{array}{l}\text { Owner } \\
\text { occupier } \\
3 \cdot 76\end{array}$ \\
\hline Employment status & $\begin{array}{l}\text { Unemployed } \\
3 \cdot 76\end{array}$ & $\begin{array}{l}\text { Employed } \\
\text { or other } \\
3.47\end{array}$ & $\begin{array}{l}\text { Unemployed } \\
3.93\end{array}$ & $\begin{array}{l}\text { Employed } \\
\text { or other } \\
3 \cdot 25\end{array}$ & $\begin{array}{l}\text { Unemployed } \\
3.94\end{array}$ & $\begin{array}{l}\text { Employed } \\
\text { or other } \\
3 \cdot 25\end{array}$ \\
\hline
\end{tabular}

EDs and wards were grouped according to whether or not the proportions of sample members in that ED or ward were below or above average in social class, tenure status, and unemployment status. The cut offs were $72 \%$ owner occupiers, $50 \%$ in manual social class, and $8 \%$ unemployed.

THE ECOLOGICAL FALLACY - OLD STYLE

Moreover, those promoting imputation, brush aside the ecological fallacy. ${ }^{3}$ Yet it is potentially alive and well in these data (table 2). Thus, the mean consultation rates for different categories of social class, tenure status, and unemployment status across all individuals registered for the full one year duration of the study period, display the expected associations (in the first pair of columns, the "poor" consult more). But, if the EDs and wards in the study are grouped according to the social class distribution, the level of owner occupancy, or the unemployment rate of study members and the means of the aggregated individual study members are then compared, the differences between study members in "unemployed" and "employed" EDs and wards is more than twice the difference between unemployed and employed individuals (see table 2). (Note that this is a strict test of the ecological fallacy because precisely the same individuals are being compared. Moreover, in most practical situations, the individual data would not be available; EDs and wards would be classified by SAS variables. This would generate a further bias.)

\section{Discussion}

Azeem Majeed $e t a l^{4}$ cite a very low correlation of 0.34 between the actual values and a synthetic estimation of the proportion of under $5 \mathrm{~s}$ in a practice. They and others have suggested that this will be improved by using ED data as the basis for synthetic estimation. But, there is no good evidence ${ }^{5}$ that patients are likely to be more representative samples of the population of an ED than of the electoral ward (if indeed there is selection, the effect might be the opposite). In the MSGP4 data, the association between socioeconomic characteristics and consultation rates at ED or ward level do not reflect those at individual level.

We thank officials at the NHS Executive, in particular, Anita Bird, Bob Edney, and Nick York; the general practices, OPCS and the RCGP; and Vanessa Waby for manuscript preparation.

1 Office of Population Censuses and Surveys. Local base statistics/small area statistics: modification of counts for conistics/small area statistics: modification

2 Royal College of General Practitioners, Office of Population

Censuses and Surveys and Department of Health. Morbidity Censuses and Surveys and Department of Health. Morbidity
statistics from general practice. Fourth national study 1991-

1992. London: HMSO, 1995.
Selvin H. Durkheim's suicide and problems of empirical research. American fournal of Sociology 1958;63:601-19.

Azeem Majeed F, Cook DG, Ross Anderson H, Hilton S Bunn S, Stones C. Using patient and general practice characteristics to explain variations in cervical smear uptake rates. $B M F$ 1994;308:1272-6.

5 Carr-Hill RA. Indexing deprivation and modelling demand. York: Centre for Health Economics; University of York. 1988. Discussion Paper No 40.

\section{Open discussion}

JOSHI - There is another way in which one can match small area statistics with individual data to explore just how fallacious or otherwise this is and that is the samples of anonymised records (SARs), available for $1 \%$ of households or $2 \%$ of individuals. Have you thought of using those?

CARR-HILL - In the next stage we are going to match the coefficients we have on the individual data to the SARs to produce synthetic estimates for those areas, but of course the areas are not very small that is the problem.

JOSHI - A student of mine has used the SAR to investigate correlation of individual attributes, for the county of Bucks.

1 Leeser R. Identifying multiple deprivation: an investigation of methods used with particular reference to housing deprivation. London: City University, 1994. Dissertation. 